\title{
嵔疑応答
}

（問）合成樹脂を含有し存い不滲透質黒鉛己 か，見掛比重が 2.0 以上の黒鉛が製作されている そうですが内容御教示下さん（大阪一S）。

（答）合成樹脂它含委い宸素製品は昨秋米 誌”により紹介されました。商品名は “Graphitite” といつて合成樹脂を含浸しでいない全カー ボンあるいは全黒鉛質で，見掛比重は高く，また 使用温度も甚索高いものです。その特性は次のよ う学多のと発表してい柰。

\begin{tabular}{|c|c|c|}
\hline 特 & A & B \\
\hline 見掛比重 $\left(\mathrm{lds} / \mathrm{ft}^{3}\right)$ & 118 & 115 \\
\hline 抗 張 力 (p.s.i) & 2600 & 2500 \\
\hline 抗压力 (") & 9000 & 8500 \\
\hline 抗折力 (") & 4800 & 4400 \\
\hline 弾性率 $\left(\times 10^{5}\right)$ & 21 & 18 \\
\hline 䅵 膨 脹 $\left(I_{n} / I_{n} /{ }^{\circ} \mathrm{F} \times 10^{-7}\right)$ & 11 & 9 \\
\hline 電気抵抗 $(\Omega$-inch) & 0.00042 & 0.00035 \\
\hline 熱伝導度 $\left(\mathrm{Btu} / \mathrm{ft}^{2} / \mathrm{F} / \mathrm{hr} / \mathrm{in}\right)$ & 1000 & 1100 \\
\hline 最高温度 (使用可能) ${ }^{\circ} \mathrm{F}$ & 1300 & 5700 \\
\hline
\end{tabular}

即ち見脚比重が約 1.9 で劃期的なるとされ季 した ( ${ }^{*}$ Chemical Engineering, Nov. 1954. p. 195)。

然亏に，今般，欧米原子力調查団の帰朝報告に よると, 西独 Sigri 社 (元のシーメンス社系) て は天然黒鉛を原料己し，見掛比重兮 2.06 黒鉛体 の製造に成功してんる由で，ての黒鉛体至原子炘 のモデレーターに使用すればウランの使用量を半 減出来当。即ち英国の BEPO 炬のウランの最低 所要量 28 屯（計算量で, 実際約 40 韷使用) て対し，ての黒鉛体をモデレーターに使朋すれば ウランの最低使用量は 13 屯でよんと説明された 由(昭和 30 年 4 月 2 日東京都産業会館における 駒形技術院長の講演による)。

\section{(30，4，6 永井雅夫)}

\section{1 炭素工業の最近の進步}

大阪工業技術試験所 工博 市 瀨 元吉

原子炬の緩速材或は反射材の量鏟が可能になつたこと は，世界の炭素工㧛界の最近の收獲である。

一方, 電子廻折, 電子湿微鏡など多くの精密測定機峨

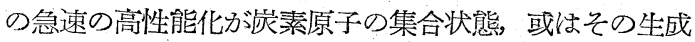
過程を解明する多くの研究拿績を生み，これが炭素製品 の品質を著しく向上させ，生廉費を崌減することになつ た。

そのことは，たと穵ば製鋼用電極，電解板刷子の如き ものの消耗量を減少させることになり生産設備の余剩を 来して，これは次々に新らしく創造される高分子化合物 と合体して不滲透崖素々の他の化学工学用炭素材料とし て，領域の搪大躍進となつた。

電気機器の性能，用途範囲が拡をれば刷子の高度の性 能が要求されてくる。眏画が天然色になれぱ，明るさ， 色温度が問題となり炭素棒の性能の向上が必然的炕結果 となつて現われる。送話器の感度も音の再生の忠実性の
高度のものの要求に対しては新らしい峞素糨となつて生 れて来た。

これ等のいくつかの事実を例にあげて解説を試夕た wo

$$
2 \text { カーボンとは }
$$

東京大学理学部 理博 赤 松 秀 雄

カーボンとはベンゼン核が多数縮合した高分子物質で めると見做す立場から，その物理化学的性暨以縮合度に 依存するものとして論ぜられる。特に電気的，磁気的性 質の特徵注縮合多環芳香族炭化水素の $\pi$ 電子の特性と乙 て理解される。さらに黒鉛化の過程に扬ける縮合度の発 達之結晶性の变化, 電気的性質, 磁気的性質の变化の関 係を実験結果について述へる。

（第 6 回炭素材料講演要旨より） 